\title{
Food allergy and PPI-responsive esophageal eosinophilia
}

\author{
Jason K Ko ${ }^{1 *}$, David JT Huang ${ }^{2}$, Jorge A Mazza² \\ From Canadian Society of Allergy and Clinical Immunology Annual Scientific Meeting 2014 \\ Ottawa, ON, Canada. 23-26 October 2014
}

\section{Background}

Eosinophilic esophagitis (EoE) is considered a chronic condition mediated by immune reaction to food and/or environmental allergens. Though first recognized decades ago, the characterization of EoE is ongoing and an important aspect of this process is the distinction between EoE and other forms of esophageal eosinophilia $[1,2]$. One group of patients exhibit marked esophageal eosinophilia ( $>15$ eo/HPF), negative esophageal $\mathrm{pH}$-monitoring studies and yet have clinicopathologic response to proton-pump inhibitor (PPI) treatment: this group is categorized as having PPI-responsive esophageal eosinophilia (PPI-REE) $[1,3]$. It is not certain whether those with PPI-REE are cases of GERD undiagnosed by $\mathrm{pH}$-monitoring, EoE responding to PPI therapy as in-vitro studies suggest [4], or some combination thereof. GERD is orders of magnitudes more prevalent than EoE and thus misdiagnosed cases of GERD could have significant impact on any study of EoE patients $[5,6]$. Other groups have attempted to distinguish cases of PPI-REE and EoE, but failed to do so using clinicopathologic criteria $[7,8]$. This retrospective review of patients diagnosed with EoE aimed to differentiate PPI-REE and non-responsive patients, with an emphasis on prevalence of food allergy between the two groups.

\section{Methods}

A chart review was performed for 30 patients diagnosed with EoE, prescribed PPI therapy and tested with atopic patch tests for a panel of food allergens. Patients were categorized as having PPI-REE if past clinical assessments noted significant symptomatic improvement with PPI therapy.

\section{Results}

Of the 30 patients reviewed, 12 were found to have PPIREE. There was no significant difference in other treatments offered to PPI-REE and non-responsive patients, the eosinophil counts at diagnosis, nor in likelihood of food allergy as detected by skin prick or food patch testing (Table 1).

\section{Conclusions}

It was hypothesized that PPI-REE cases would be less atopic, with regards to foods, than non-responders due to the possible prevalence of undiagnosed GERD in the former group. However, this review failed to show any statistically significant differences between the two groups. This is consistent with attempts of other groups to distinguish PPI-REE and EoE patients.

\section{Authors' details \\ 'Schulich School of Medicine \& Dentistry, University of Western Ontario, London, Ontario, Canada. ${ }^{2}$ Division of Allergy \& Clinical Immunology, Department of Medicine, University of Western Ontario, London, Ontario, Canada.}

Published: 18 December 2014

\section{References}

1. Liacouras CA, Furuta GT, Hirano I, Atkins D, Attwood SE, Bonis PA, Burks AW, Chehade M, Collins MH, Dellon ES, et al: Eosinophilic esophagitis: updated consensus recommendations for children and adults. The Journal of allergy and clinical immunology 2011, 128:3-20, e26; quiz 21-22.

2. Rodrigo S, Abboud G, Oh D, DeMeester SR, Hagen J, Lipham J, DeMeester TR, Chandrasoma P: High intraepithelial eosinophil counts in esophageal squamous epithelium are not specific for eosinophilic esophagitis in adults. The American journal of gastroenterology 2008, 103:435-442.

3. Molina-Infante J, Ferrando-Lamana L, Ripoll C, Hernandez-Alonso M, Mateos JM, Fernandez-Bermejo M, Duenas C, Fernandez-Gonzalez N, Quintana EM, Gonzalez-Nunez MA: Esophageal eosinophilic infiltration responds to proton pump inhibition in most adults. Clinical gastroenterology and hepatology: the official clinical practice journal of the American Gastroenterological Association 2011, 9:110-117. 
Table 1 Characteristics of PPI-REE and non-responder groups.

\begin{tabular}{cccc}
\hline & PPI-REE & Non-responders & p-value \\
\hline $\boldsymbol{N}$ & 12 & 18 & $\mathrm{~N} / \mathrm{A}$ \\
\hline Average eosinophil count at diagnosis (eo/HPF) & $65.7 \pm 29.2$ & $42.6 \pm 15.6$ & 0.14 \\
\hline Use of other treatments (Swallowed steroid and/or dilatation) & $10 / 12(83 \%)$ & $8 / 18(44 \%)$ & 0.21 \\
\hline Food allergy on atopic patch test & $9 / 12(75 \%)$ & $9 / 18(50 \%)$ & 0.60 \\
\hline Food allergy on skin prick test & $5 / 11(45 \%)$ & $6 / 16(38 \%)$ & 0.98 \\
\hline
\end{tabular}

4. Zhang X, Cheng E, Huo X, Yu C, Zhang Q, Pham TH, Wang DH, Spechler SJ, Souza RF: Omeprazole blocks STAT6 binding to the eotaxin-3 promoter in eosinophilic esophagitis cells. PloS one 2012, 7:e50037.

5. Dent J, El-Serag HB, Wallander MA, Johansson S: Epidemiology of gastrooesophageal reflux disease: a systematic review. Gut 2005, 54:710-717.

6. Hruz P: Epidemiology of eosinophilic esophagitis. Digestive diseases 2014 32:40-47.

7. Dellon ES, Speck O, Woodward K, Gebhart JH, Madanick RD, Levinson S, Fritchie KJ, Woosley JT, Shaheen NJ: Clinical and endoscopic characteristics do not reliably differentiate PPI-responsive esophageal eosinophilia and eosinophilic esophagitis in patients undergoing upper endoscopy: a prospective cohort study. The American journal of gastroenterology 2013, 108:1854-1860.

8. Moawad FJ, Schoepfer AM, Safroneeva E, Ally MR, Chen YJ,

Maydonovitch CL, Wong RK: Eosinophilic oesophagitis and proton pump inhibitor-responsive oesophageal eosinophilia have similar clinical, endoscopic and histological findings. Alimentary pharmacology \& therapeutics 2014, 39:603-608.

doi:10.1186/1710-1492-10-S2-A25

Cite this article as: Ko et al:: Food allergy and PPI-responsive esophageal eosinophilia. Allergy, Asthma and Clinical Immunology 2014 10(Suppl 2):A25.

\section{Submit your next manuscript to BioMed Central} and take full advantage of:

- Convenient online submission

- Thorough peer review

- No space constraints or color figure charges

- Immediate publication on acceptance

- Inclusion in PubMed, CAS, Scopus and Google Scholar

- Research which is freely available for redistribution

Submit your manuscript at www.biomedcentral.com/submit
Biomed Central 